\title{
Effect of Gérce alginit on the fertility of an acid sandy soil
}

\author{
${ }^{1}$ I. KÁDÁR, ${ }^{1}$ P. RAgÁlyi, ${ }^{1}$ A. MurÁNYI, ${ }^{1}$ L. RADimSZKY and ${ }^{2}$ A. GAJdó \\ ${ }^{1}$ Institute for Soil Science and Agricultural Chemistry, CAR, HAS, Budapest \\ ${ }^{2}$ Alginit Ltd., Budapest
}

\section{Introduction}

Alginit is an oil shale rock with a high organic matter content, which was formed 3-4 million years ago from fossil (buried and petrified) algae biomass and decayed tufa, at a time when craters (tufa rings, maars) were formed after a period of violent volcanic activity. The water of the upper Pannonian inland sea then leaked into the basin of the craters. Green algae (Botryococcus brauni) and other plants/animals proliferated in the nutrient-rich, low salinity waters of the crater lakes, resulting in eutrophication. Mortified in anaerobic conditions, they accumulated at the bottom of the lake as sapropelic mud (SOLTI, 1999).

The name "alginit" indicates its algal biomass origin. Sixty-four elements were identified from alginit rock, most of them located in the inorganic bonds of triplelayered silicates and in the organic or chelate bonds of humus materials. Clay minerals (smectite, illite), carbonates (calcite, dolomite) and amorphous quartz and silica are the dominant mineral components, while gypsum, plagioclase, K-feldspar, siderite, goethite, pyrite and magnesite can also be found in smaller amounts. In 1974, within the framework of the mapping research programme of the Geological Institute of Hungary (MÁFI), Gábor Solti explored one-time volcanic craters buried in alginit and basalt bentonite (SOLTI, 1999).

According to present knowledge, alginit can be found exclusively in the Carpathian Basin, in a quantity of approximately 150 million tons. Opencast mining is economical at three locations. The stock of these three mines represents about $90 \%$ of the total resources. Only two mines are in operation, the most significant of which is located in Gérce and owns about $80 \%$ of the total alginit. According to drillings made in recent years, alginit forms a layer with an average thickness of $40-60 \mathrm{~m}$ on the surface of about $200 \mathrm{ha}$, with 100 million tons of recoverable reserves. The mine currently operates on 16 ha.

The Soil Protection Laboratory of the Hungarian Agricultural Office in Tanakajd analysed three alginit samples in 2009. The average composition of the samples was as follows: moisture $37 \%, \mathrm{CaCO}_{3} 15 \%$, microelements/heavy metals: $\mathrm{Pb}$

Correspondence to: IMRE KÁDÁR, Institute for Soil Sciences and Agricultural Chemistry, Centre for Agricultural Research, Hungarian Academy of Sciences, H-1022 Budapest, 15 Herman Ottó út. Hungary. E-mail: kadar@rissac.hu 
93, Cr 62, Cu 22, Ni 21, Co 20, As 10, Se $<0.5, \mathrm{Cd}<0.2$ and $\mathrm{Hg}<0.1 \mathrm{mg} \cdot \mathrm{kg}^{-1}$ dry matter. The Hungarian Agricultural Office licensing authority has granted a licence for commercial use, since the product has no hazardous components, hazardous waste or other hazardous materials above the permitted limit values.

According to the quality criteria described in the licence, alginit is a brown, odourless, moist, soil-like material suitable for use as a soil ameliorant. It contains a maximum of $40 \%$ moisture, at least $14 \% \mathrm{CaCO}_{3}$ and organic material, with upper limit concentrations $\left(\mathrm{mg} \cdot \mathrm{kg}^{-1}\right)$ of $100 \mathrm{Cu}, \mathrm{Cr}$ and $\mathrm{Pb}, 50 \mathrm{Co}$ and $\mathrm{Ni}, 10 \mathrm{As}, 5 \mathrm{Se}, 2$ $\mathrm{Cd}$ and $1 \mathrm{Hg}$. It is licensed for use for the amelioration of acid soils and as an additive for growing mediums until $8^{\text {th }}$ September 2019 (MSzHK, 2009).

According to analyses carried out by the Department of Soil Science, University of Bonn and LUFA Nord-West, alginit from Gérce contains 52\% clay, $42 \%$ silt and $6 \%$ sand. After the breakdown of carbonates and humus materials, the clay fraction drops to half, i.e. $26 \%$, while the silt fraction rises to $67 \%$. The reduction in the clay content is due to the disappearance of fine-structured lime from the alginit.

$1 \mathrm{~m}^{3}$ alginit is able to retain about $600 \mathrm{~kg}$ water, about 400 litres of which remains available for plants. According to X-ray diffraction analysis, clay minerals are represented by $50 \%$ smectite, $40 \%$ illite, and $10 \%$ chlorite/vermiculite. The swelling of smectite improves the water-holding capacity of the rock. The organic matter content may vary from $6-19 \%$. However, the $\mathrm{C} / \mathrm{N}$ ratio is above 30 and the organic material is stable, with a long half-life. The $\mathrm{CaCO}_{3}$ content may be as high as $20 \%$, while the CEC has a value of $35 \mathrm{~mol} \cdot \mathrm{kg}^{-1}$. These properties may be particularly advantageous for ameliorating unstructured acidic sandy soils with poor water and nutrient supplies. According to the alginit data sheet, alginit is heterogeneous, making an accurate determination of its composition and quality impossible (TNR GMBH, 2010).

The effect of Gérce alginit on the properties of an acidic sandy soil and on spinach growing in $6 \mathrm{~kg}$ Mitscherlich pots with uniform additional NPKMgS fertilization was studied in Germany. Alginit was mixed with soil in ratios of $0,10,15$ and $20 \%$. The cation exchange capacity (CEC) of the soil increased to 2, 26, 38, 44 $\mathrm{cmol} \cdot \mathrm{kg}^{-1}$, respectively, with the doses, so the increment was $10-20$-fold. The shoot and root mass of spinach increased by $20-30 \%$. In particular, the mass of fine, long roots became significant. Overall, a more stable soil structure was established, and the water and nutrient use efficiency of the plants became more favourable. The $\mathrm{pH}$ of the soil rose and the water storage capacity increased by $7-10 \%$. In leaching tests, considerable quantities of $\mathrm{Ca}, \mathrm{Mg}, \mathrm{K}$ and $\mathrm{Ni}$ left the alginit-treated soil with the percolating water, while the amount of $\mathrm{P}$ decreased with increasing alginit doses. Unfortunately, the composition and quality characteristics of the alginit were not published by the authors (REX \& SCHERER, 2010).

A micro-plot field experiment was set up on raw calcareous sandy soil with uniform NPK fertilization in Egypt in order to study the ameliorative effects of alginit at application rates of $0,4,8$ and $16 \mathrm{~kg} \cdot \mathrm{m}^{-2}$, i.e. $0,40,80$ and $160 \mathrm{t} \cdot \mathrm{ha}^{-1}$. The established grass was irrigated every day from May till September. Under similar conditions $8-10 \mathrm{~kg} \cdot \mathrm{m}^{-2}$, i.e. $80-100 \mathrm{t} \cdot \mathrm{ha}^{-1}$ finely ground alginit is recommended, mixed with soil to a depth of $10 \mathrm{~cm}$. In response to the treatment, the structure and water- 
holding capacity of sandy soil improved. Longer, finer grass roots were formed, which interwove the soil better, thus stimulating the uptake of nutrients and water. The plant-available water content increased from $6 \%$ to $10 \%$, while the water storage capacity rose from 120 to $150 \mathrm{~m}^{3} \cdot \mathrm{ha}^{-1}$, an increment of $12-15 \mathrm{~mm} \cdot \mathrm{ha}^{-1}$. When mixed into the $10 \mathrm{~cm}$ layer, the alginit ratio was higher, so the treatment was more efficient than when it was distributed in $20 \mathrm{~cm}$ of soil. The finely ground $(<2 \mathrm{~mm})$ fraction of alginit was also more advantageous, according to the author, but again the composition of the alginit was not published (HELAL, 2010).

A comparison of the characteristics of alginit, communal compost from Gödöllö, sandy soil from Nyírlugos and loamy soil from Nagyhörcsök is shown in Table 1.

Table 1

Comparison of the characteristics of alginit, communal compost from Gödöllö, sandy soil from Nyírlugos and loamy soil from Nagyhörcsök (Institute for Soil Science and Agricultural Chemistry, CAR HAS)

\begin{tabular}{|l|c|c|c|c|c|}
\hline Characteristics & Unit & Alginit & $\begin{array}{c}\text { Communal } \\
\text { compost }\end{array}$ & $\begin{array}{c}\text { Sandy soil } \\
\text { (Nyírlugos) }\end{array}$ & $\begin{array}{c}\text { Loamy soil } \\
\text { (Nagyhörcsök) }\end{array}$ \\
\hline $\mathrm{pH}\left(\mathrm{H}_{2} \mathrm{O}\right)$ & - & $7.0-7.8$ & $7.0-8.0$ & $4.8-5.8$ & $7.8-8.1$ \\
$\mathrm{pH}(\mathrm{KCl})$ & & $6.9-7.4$ & $6.0-7.0$ & $4.0-4.2$ & $7.5-7.7$ \\
Sand & & $10-20$ & $60-65$ & $86-92$ & $15-20$ \\
$\mathrm{Silt}$ & $\%$ & $40-50$ & $20-25$ & $5.0-9.0$ & $55-60$ \\
Clay & & $40-50$ & $10-15$ & $3.0-5.0$ & $20-25$ \\
Saturation & $\%$ & $60-90$ & - & $23-25$ & $38-40$ \\
percentage & & $5-20$ & $5-8$ & - & $3-5$ \\
CaCO & $\%$ & $5-13$ & $30-40$ & $0.5-0.8$ & $2-4$ \\
Humus & & $0.2-0.4$ & $0.4-0.6$ & $<0.02$ & 0.02 \\
"Total" salt & $\%$ & $0.1-0.4$ & $1.0-3.0$ & $<0.05$ & $0.1-0.2$ \\
Total N & & $30-180$ & $7-8$ & - & $10-15$ \\
C/N ratio & - & & & & \\
\hline
\end{tabular}

Alginit may contain extremely high amounts of clay, which is also indicated by the high $\mathrm{K}_{\mathrm{A}}$ value (saturation). In addition, its $\mathrm{CaCO}_{3}$ and organic matter content are also outstanding. However, it does not supply $\mathrm{N}$ for the plants, since it has an extremely high $\mathrm{C} / \mathrm{N}$ ratio. Thus, alginit application should be accompanied by additional $\mathrm{N}$ supplies, as it may be ineffective without $\mathrm{N}$. The statement that alginit application ensures a complex supply of macro- and microelements in the soil for the development of plants and that it could act as a substitute for fertilizers and compensate the lack of organic manures is thus misleading (BANOS, 1999).

There can be little doubt that the slightly alkaline or neutral $\mathrm{pH}$, the large amounts of $\mathrm{Ca}$ and $\mathrm{Mg}$ (and in some cases $\mathrm{K}, \mathrm{S}$ and $\mathrm{P}$ ), the excellent water storage capacity and the rich content of organic and mineral colloids in alginit make it suitable for improving the quality and fertility of acid, loose-structured, colloid-poor sandy soils. Alginit can also improve the water and nutrient supply characteristics when combined with $\mathrm{N}$ fertilizer. 
The drought tolerance of the plants may be enhanced. Due to its colloidal structure alginit is able to bind soil contaminants (detoxification), and may hinder their leaching into the groundwater. On acid sandy soils, alginit can be expected to have liming, $\mathrm{pH}$-increasing and colloid-enhancing effects when it is applied in ameliorative doses.

Factors limiting the utilization of alginit:

- It needs to be transported, applied and manipulated in large quantities (10-100 $\left.\mathrm{t} \cdot \mathrm{ha}^{-1}\right)$

- Mined, deposited, "ready to sell" alginit has an average moisture content of 20$25 \%$.

- In Hungary it is the soils of the Nyírség and inner Somogy regions that are most in need of amelioration. These are the poorest regions of the country, so the operation will require financial support from the government.

- The Ni content of alginit may reach or even exceed the permitted $50 \mathrm{mg} \cdot \mathrm{kg}^{-1}$ dry matter (DM) limit value.

This latter fact has no agronomical, physiological or environmental impact, since $\mathrm{Ni}$ will not be mobilized and taken up by plants in this calcareous medium.

\section{Materials and Methods}

One of the oldest long-term field experiments in Hungary is in Nyírlugos, in the Nyírség region. It was set up by LÁNG (1963) on acidic sandy brown forest soil with thin interstratified layers of colloid and sesquioxide accumulation, known as "kovárvány". The effects of five elements were studied in the experiment, with four levels of N, P, K and Ca and three levels of Mg. The fertilizers were applied in the form of Ca-ammonium-nitrate, superphosphate, muriate of potash, ground limestone and dolomite powder. There were 32 treatments with 4 replications, giving a total of 128 plots, each measuring $5 \times 10=50 \mathrm{~m}^{2}$, arranged in a randomized factorial block design. The original number of plots was 512, as the effects of cultivars and ploughing depth were also studied. Triticale has been grown in a monoculture in the experiment since 1991. The conditions and the lessons learned from the 50 years of the experiment were described in more detail by KÁDÁR et al. (2011).

Alginit was applied on a single occasion at an ameliorative rate of $100 \mathrm{t} \cdot \mathrm{ha}^{-1}$ in combination with four $\mathrm{N}$ doses $\left(0,50,100\right.$ and $\left.150 \mathrm{~kg} \cdot \mathrm{ha}^{-1} \cdot \mathrm{year}^{-1}\right)$. The soil of these plots was acidified and depleted in $\mathrm{Ca}, \mathrm{Mg}, \mathrm{K}$ and $\mathrm{P}$ due to the high rate of $\mathrm{N}$ fertilization. The plots were halved in autumn 2011 and half the resulting $25 \mathrm{~m}^{2}$ plots were treated with $100 \mathrm{t} \cdot \mathrm{ha}^{-1}$ alginit, i.e. $250 \mathrm{~kg}$ per plot. The alginit was applied evenly by hand and then mixed into the soil by ploughing and disking. Plots given no alginit served as the control. There were thus $4 \mathrm{~N} \times 4$ replications $=16$ treatments with alginit, and $4 \mathrm{~N} \times 4$ replications $=16$ treatments without alginit, giving a total of 32 plots.

The data were statistically evaluated using two-factor multivariate analysis of variance, where the independent variables were the different doses of alginit and nitrogen. 


\section{Characterization of the alginit applied}

The alginit contained $15 \%$ moisture, $15 \% \mathrm{CaCO}_{3}$ and $4.6 \%$ organic matter. Total-N was $0.15 \%, \mathrm{~K}_{\mathrm{A}} 63, \mathrm{AL}-\mathrm{K}_{2} \mathrm{O} 386$ and $\mathrm{AL}-\mathrm{P}_{2} \mathrm{O}_{5} 216 \mathrm{mg} \cdot \mathrm{kg}^{-1}$. The estimated $\mathrm{C} / \mathrm{N}$ ratio was about 180 . An ameliorative dose of $100 \mathrm{t} \cdot \mathrm{ha}^{-1}$ alginit was applied on a single occasion in order to study its effect on the physical and water management characteristics of the soil. Table 2 shows the aqua regia-soluble "total" and $\mathrm{NH}_{4}$ acetate+EDTA-soluble "mobile" element contents of the alginit, the proportion of the mobile fraction (\%) compared to the "total" and the soil load represented by the $100 \mathrm{t} \cdot \mathrm{ha}^{-1}$ dose.

The alginit contained about $5 \% \mathrm{Ca}, 3.6 \% \mathrm{Al}, 2.9 \% \mathrm{Fe}, 1.9 \% \mathrm{Mg}, 0.82 \% \mathrm{~K}$ $0.15 \% \mathrm{P}$ and $0.12 \% \mathrm{~S}$. The aqua regia-soluble $\mathrm{Ni}$ content exceeded the $50 \mathrm{mg} \cdot \mathrm{kg}^{-1}$ DM limit value.

Table 2

Aqua regia-soluble "total" and $\mathrm{NH}_{4}$-acetate + EDTA-soluble "mobile" element contents $\left(\mathrm{mg} \cdot \mathrm{kg}^{-1}\right)$ of the alginit and the soil load represented by the $100 \mathrm{t} \cdot \mathrm{ha}^{-1}$ dose

(Nyírlugos long-term field experiment, Nyírség region, 2011)

\begin{tabular}{|c|c|c|c|c|}
\hline Element & $\begin{array}{l}\text { Aqua regia- } \\
\text { soluble }\end{array}$ & $\begin{aligned} & \mathrm{NH}_{4} \text {-acetate } \\
+ & \text { EDTA-soluble }\end{aligned}$ & $\begin{array}{l}\text { Mobile \% } \\
\text { of the total }\end{array}$ & Soil load* \\
\hline $\mathrm{Ca}$ & 49942 & 43965 & 88 & 4245 \\
\hline $\mathrm{Al}$ & 36026 & 68 & $<1$ & 3062 \\
\hline $\mathrm{Fe}$ & 28501 & 934 & 3 & 2423 \\
\hline $\mathrm{Mg}$ & 19188 & 6969 & 36 & 1631 \\
\hline $\mathrm{K}$ & 8166 & 466 & 6 & 694 \\
\hline $\mathrm{P}$ & 1501 & 35 & 2 & 128 \\
\hline $\mathrm{S}$ & 1237 & 703 & 57 & 105 \\
\hline $\mathrm{Mn}$ & 587 & 411 & 70 & 50 \\
\hline $\mathrm{Na}$ & 454 & 230 & 51 & 39 \\
\hline $\mathrm{Sr}$ & 419 & 322 & 77 & 36 \\
\hline $\mathrm{Ba}$ & 281 & 84 & 30 & 24 \\
\hline $\mathrm{Ni}$ & 75.0 & 14.50 & 19 & 6.4 \\
\hline $\mathrm{Zn}$ & 65.8 & 5.22 & 8 & 5.6 \\
\hline $\mathrm{Cr}$ & 63.9 & 0.42 & $<1$ & 5.4 \\
\hline $\mathrm{B}$ & 26.8 & 0.34 & 1 & 2.3 \\
\hline $\mathrm{Cu}$ & 19.2 & 7.04 & 37 & 1.6 \\
\hline $\mathrm{Co}$ & 15.9 & 2.80 & 18 & 1.4 \\
\hline $\mathrm{Pb}$ & 9.75 & 3.92 & 40 & 0.85 \\
\hline As & 8.84 & 0.44 & 5 & 0.76 \\
\hline $\mathrm{Sn}$ & 2.84 & 0.14 & 5 & 0.25 \\
\hline Mo & 1.86 & 0.06 & 3 & 0.17 \\
\hline $\mathrm{Se}$ & 1.02 & $<0.12$ & - & 0.08 \\
\hline $\mathrm{Cd}$ & 0.12 & 0.11 & 92 & 0.01 \\
\hline
\end{tabular}

Note: *Soil load represented by $100 \mathrm{t} \cdot \mathrm{ha}^{-1}$ alginit based on the aqua regia element content 
In terms of chemical solubility (which is not linked directly to plant availability), the $70-92 \%$ mobile fraction ratio of $\mathrm{Cd}, \mathrm{Ca}, \mathrm{Sr}$ and $\mathrm{Mn}$, in descending order, was conspicuous. These were followed by $\mathrm{S}, \mathrm{Na}, \mathrm{Pb}, \mathrm{Cu}, \mathrm{Mg}$ and $\mathrm{Ba}$ with $30-57 \%$ mobile fraction ratios. The mobile fractions of $\mathrm{Ni}$ and $\mathrm{Co}$ only amounted to 18 $19 \%$, while those of the other elements remained below $10 \%$. The mobile fraction was about $1 \%$ or less in the case of $\mathrm{Al}, \mathrm{Cr}$ and $\mathrm{B}$, which are incorporated into the crystal lattices (Table 2 ).

With the $100 \mathrm{t} \cdot \mathrm{ha}^{-1}$ dose the ploughed soil layer was loaded with $4.2 \mathrm{t} \mathrm{Ca}, 3.1 \mathrm{t}$ $\mathrm{Al}, 2.4 \mathrm{t} \mathrm{Fe}, 1.6 \mathrm{t} \mathrm{Mg}, 694 \mathrm{~kg} \mathrm{~K}, 128 \mathrm{~kg} \mathrm{P}$ and $105 \mathrm{~kg} \mathrm{~S}$ per hectare. The total Ni, $\mathrm{Zn}$ and $\mathrm{Cr}$ load was about 5-6 kg.ha ${ }^{-1}$ and that of $\mathrm{B}, \mathrm{Cu}$ and $\mathrm{Co} 1-2 \mathrm{~kg} \cdot \mathrm{ha}^{-1}$, while the amount of the remaining microelements could only be expressed in decagrams. The quantity of $\mathrm{Hg}$ was below the detection limit.

Since alginit is rich in $\mathrm{Ca}$ and $\mathrm{Mg}$ and relatively rich in $\mathrm{K}, \mathrm{P}$ and $\mathrm{S}$, it can replace liming materials and, to a lesser extent, $\mathrm{K}, \mathrm{P}$ and $\mathrm{S}$ fertilizers. However, it cannot serve as a $\mathrm{N}$ source, so proper $\mathrm{N}$ fertilization is essential for a lasting and positive effect.

\section{Plant and soil sampling}

Plant samples were taken each year at the ripening stage from the aboveground plant material on an area of $1 \mathrm{~m}^{2}$ from the centre of each plot to avoid the border effect (net plots). The samples were threshed, the grain/straw/husk weights were measured $(\mathrm{n}=32)$ and the plant material was milled for laboratory analysis. Soil samples were taken from the ploughed layer after disk-harrowing on 20 July 2012, mixing the samples of 20 drills per plot (representative average sample, $n=32$ ) to determine the basic properties and elemental composition of the soil. For soil physical testing (field capacity and effective water) two cylinders were placed in the ploughed layer on the control plots and three on the alginit-treated plots (the larger number of cylinders being required due to soil heterogeneity). There were thus 4 treatments $\times 2$ cylinders $\times 2$ replications $=16$ samples in the control and 4 treatments $\times 3$ cylinders $\times 2$ replications $=24$ samples in the alginit treatment, giving a total of 40 tests on undisturbed soil samples. It is planned to perform plant and soil analysis every five years.

\section{Chemical analyses}

Laboratory analyses were conducted in the Institute for Soil Science and Agricultural Chemistry, AKT HAS, using the following methods:

Plant samples: air-dry material weighing $0.5 \mathrm{~g}$ was treated with $5 \mathrm{~cm}^{3} \mathrm{cc} . \mathrm{HNO}_{3}$ $+1 \mathrm{~cm}^{3} \mathrm{cc} . \mathrm{H}_{2} \mathrm{O}_{2}$, and then digested for $15 \mathrm{~min}$ in a microwave oven. Element concentrations were measured in an ICP detector.

Soil and alginit samples: The LAKANEN and ERVIÖ (1971) method was used to analyse the soluble element content. The aqua regia-soluble "total" element content was measured using $\mathrm{HCl}+65 \% \mathrm{HNO}_{3}+30 \% \mathrm{H}_{2} \mathrm{O}_{2}$. 
Element concentrations were measured in an ICP detector. Tests on the $\mathrm{pH}, \mathrm{y}_{1}$, $\mathrm{CaCO}_{3}$, humus, water holding capacity, total salt and total bases were performed according to BARANYAI et al. (1987). Exchangeable cations and T-value were measured with $2.5 \mathrm{~g}$ soil by adding $30 \mathrm{~cm}^{3} 1 \mathrm{~mol} / \mathrm{L} \mathrm{BaCl}_{2}+$ trietanol-amin (TEA) shaking solution (JOU et al., 1976). After three hours shaking, the elements were measured with an ICP device according to the Hungarian Standards MSZ 08-02141:1978 and MSZ 08-0214-2:1978 and BASCOMB (1964). The S-value was calculated as a sum of $\mathrm{Ca}, \mathrm{Mg}, \mathrm{K}$ and $\mathrm{Na}$ exchangeable cations. The difference $\mathrm{T}-\mathrm{S}$ indicates the number of adsorption sites not bound by bases, expressed in me/100 g soil. $\mathrm{V} \%$ refers to base saturation, indicating the percentage of possible adsorption sites fixed by 1 - and 2 -valence base cations $(\mathrm{V}=\mathrm{S} \cdot 100 / \mathrm{T})$. Thus, V\% is saturation expressed as a $\%$ of the T-value. Its inverse (reciprocal) value may also be used to indicate the $\%$ unsaturation of $\mathrm{T}(\mathrm{U}=100-\mathrm{V})$.

\section{Physical soil analysis}

The water capacity and field capacity were characterized as two points on the $\mathrm{pF}$ curve. The $\mathrm{pF}=0$ point, corresponding to total water capacity, was determined from the water saturation of the undisturbed soil columns. Saturation and field capacity water contents were determined on the undisturbed soil cores according to BUZÁs (1993). Moisture content of the collected soil samples were determined by ovendrying (BUZÁS, 1993).

\section{Precipitation}

Monthly and yearly sums of precipitation and the 50-year mean are shown in Table 3.

Table 3

Monthly and yearly sums of precipitation between 2011 and 2014, and the 50-year mean, $\mathrm{mm}$ (Nyírlugos long-term field experiment, Nyírség region)

\begin{tabular}{|c|c|c|c|c|c|}
\hline Months & 2011 & 2012 & 2013 & 2014 & 50-year mean \\
\hline January & 33 & 26 & 28 & 32 & 27 \\
February & 11 & 11 & 46 & 28 & 29 \\
March & 41 & 1 & 132 & 15 & 30 \\
April & 19 & 32 & 47 & 24 & 41 \\
May & 34 & 85 & 82 & 79 & 59 \\
June & 42 & 53 & 29 & 27 & 65 \\
July & 133 & 53 & 34 & 122 & 65 \\
August & 34 & 8 & 16 & 57 & 50 \\
September & 28 & 19 & 22 & 33 & 46 \\
October & 29 & 30 & 45 & 65 & 37 \\
November & 1 & 28 & 27 & 18 & 42 \\
December & 50 & 55 & 3 & 35 & 41 \\
Yearly sums & 454 & 401 & 511 & 535 & 534 \\
\hline
\end{tabular}


The data showed that during the nine-month growing season of triticale only 288 $\mathrm{mm}$ of rain fell in the first year, between October 2011 and June 2012, which did not allow the formation of high crop yields in 2012.

The year 2013 was extremely unfavourable. In the spring months of March, April and May the rain was unusually heavy and this period was accompanied by low temperature. The growth of triticale was retarded, and the stand thinned and became infested with weeds. The weather was extremely hot and dry in June and July, corresponding to the generative phase from flowering till ripening, which determines the crop yield. The seed could not develop, so alginit was unable to exert its yield-increasing effect because of the water shortage.

2014 was favourable, due to the abundant rainfall in May. The further rainfall in June, however, was mostly favourable for the development of straw and weeds.

\section{Results and discussion}

\section{Effect of $N x$ alginit treatments on some physical parameters of the soil}

The physical soil tests carried out in 2012 showed that neither $\mathrm{N}$ fertilization nor alginit treatment had a significant effect on the total porosity of the soil. The total pore volume was $47.5 \%$, so the volume of the solid phase of the soil was $52.5 \%$. Field capacity, i.e. the amount of water stored in the capillary pores, increased from $21-28 \%$ of the control to $28-34 \%$ (with an increase in the mean from $26 \%$ to $31 \%$ ). This difference, though far from negligible, was not significant, but may have contributed to the positive yield-increasing effect of the dry years.

The soil moisture on 26 September 2012 averaged 5.8\% in the control and 7.2\% in the alginit treatment, equivalent to an increment of $23 \%$. This could be attributed to the organic and mineral colloids added to the soil with alginit, which is also supported by the significant increase in the saturation percentage $\left(\mathrm{K}_{\mathrm{A}}\right.$ according to Arany) from 30.2 to 31.6 on average, as a result of the alginit treatment.

\section{Effect of $N x$ alginit treatments on some chemical parameters of the soil}

The results of the 2012 soil analysis also showed that excessive $\mathrm{N}$ fertilization reduced the $\mathrm{pH}$, so that the soil became extremely acidified over the past halfcentury. At the same time the cation exchange capacity (CEC or T-value) decreased, as did the quantity of bases, or S-value. In the alginit treatment, the average $\mathrm{pH}\left(\mathrm{H}_{2} \mathrm{O}\right)$ increased from 5.20 to 6.66 and the $\mathrm{pH}(\mathrm{KCl})$ value from 3.87 to 6.16 . The acidic sandy soil became practically neutral (Table 4 ).

The electrical conductivity (EC) tripled, while the CEC and S-value also nearly tripled. EC increased from 21 to $67 \mathrm{mS} \cdot \mathrm{cm}^{-1}$, while $\mathrm{K}_{\mathrm{A}}$ value (saturation percentage) rose from 30.2 to 31.6 in response to alginit treatment. The base saturation of the soil increased from 53 to $74 \%$. 
Table 4

Effect of $\mathrm{N}$ and alginit treatments on some soil parameters in the ploughed layer, 2012

\begin{tabular}{|c|c|c|c|c|c|c|}
\hline \multirow{2}{*}{\begin{tabular}{|c|} 
N rate \\
$\mathrm{kg} \cdot \mathrm{ha}^{-1} \cdot \mathrm{yr}^{-1}$
\end{tabular}} & \multirow{2}{*}{$\begin{array}{c}\mathrm{pH} \\
\left(\mathrm{H}_{2} \mathrm{O}\right)\end{array}$} & \multirow{2}{*}{$\underset{(\mathrm{KCl})}{\mathrm{pH}}$} & \multirow{2}{*}{$\begin{array}{l}\text { Hydrolytic } \\
\text { acidity }\left(\mathrm{y}_{1}\right)\end{array}$} & CEC & S-value & \multirow{2}{*}{$\begin{array}{c}\begin{array}{c}\text { Base } \\
\text { saturation }\end{array} \\
\% \\
\end{array}$} \\
\hline & & & & \multicolumn{2}{|c|}{$\mathrm{me} / 100 \mathrm{~g}$} & \\
\hline \multicolumn{7}{|c|}{ Without alginit (control) } \\
\hline 0 & 5.69 & 4.17 & 7.5 & 2.0 & 1.1 & 54 \\
\hline 50 & 5.22 & 3.88 & 9.3 & 2.1 & 1.1 & 52 \\
\hline 100 & 5.00 & 3.77 & 12.4 & 1.8 & 1.0 & 54 \\
\hline 150 & 4.89 & 3.67 & 12.3 & 1.5 & 0.8 & 51 \\
\hline \multicolumn{7}{|c|}{ Alginit, $100 t \cdot h a^{-1}$} \\
\hline 0 & 6.75 & 6.25 & 5.1 & 3.4 & 2.5 & 74 \\
\hline 50 & 6.76 & 6.26 & 5.3 & 4.5 & 3.5 & 77 \\
\hline 100 & 6.67 & 6.23 & 6.6 & 3.5 & 2.6 & 74 \\
\hline 150 & 6.49 & 5.92 & 7.3 & 2.9 & 2.0 & 70 \\
\hline $\mathrm{LSD}_{5 \%}$ & 0.25 & 0.36 & 2.8 & 1.2 & 0.7 & 12 \\
\hline \multicolumn{7}{|c|}{ Means of $N$ treatments } \\
\hline Control & 5.20 & 3.87 & 10.4 & 1.3 & 1.0 & 53 \\
\hline Alginit & 6.66 & 6.16 & 6.1 & 3.6 & 2.6 & 74 \\
\hline $\mathrm{LSD}_{5 \%}$ & 0.13 & 0.18 & 1.4 & 0.6 & 0.4 & 6 \\
\hline
\end{tabular}

Table 5

Effect of $\mathrm{N}$ and alginit on the proportion of exchangeable cations in the ploughed layer, 2012

\begin{tabular}{|c|c|c|c|c|c|c|}
\hline $\mathrm{N}$ rate & $\mathrm{Ca}^{2+}$ & $\mathrm{Mg}^{2+}$ & $\mathrm{Al}^{3}$ & $\mathrm{Fe}^{3+}$ & $\mathrm{K}^{+}$ & \multirow[t]{2}{*}{ Total } \\
\hline $\mathrm{kg} \cdot \mathrm{ha}^{-1} \cdot \mathrm{yr}^{-1}$ & \multicolumn{5}{|c|}{$\%$ of S-value } & \\
\hline \multicolumn{7}{|c|}{ Control } \\
\hline 0 & 61 & 12 & 18 & 6 & 3 & 100 \\
\hline 50 & 55 & 14 & 17 & 8 & 6 & 100 \\
\hline 100 & 40 & 12 & 21 & 15 & 2 & 100 \\
\hline 150 & 35 & 12 & 24 & 22 & 7 & 100 \\
\hline \multicolumn{7}{|c|}{ Alginit, $100 t \cdot h a^{-1}$} \\
\hline 0 & 82 & 13 & 2 & 2 & 1 & 100 \\
\hline 50 & 78 & 14 & 1 & 5 & 2 & 100 \\
\hline 100 & 80 & 14 & 2 & 3 & 1 & 100 \\
\hline 150 & 78 & 15 & 3 & 3 & 1 & 100 \\
\hline $\mathrm{LSD}_{5 \%}$ & 24 & 6 & 4 & 6 & 4 & \\
\hline \multicolumn{7}{|c|}{ Means of $N$ treatments } \\
\hline Control & 48 & 13 & 20 & 13 & 5 & 100 \\
\hline Alginit & 80 & 14 & 2 & 3 & 1 & 100 \\
\hline $\mathrm{LSD}_{5 \%}$ & 12 & 3 & 2 & 3 & 2 & \\
\hline F-value & $* * *$ & NA & $* * *$ & $* * *$ & $* * *$ & \\
\hline
\end{tabular}

Note: F-value: *95, **99, ***99.9\% interval of significance; NA: not available 
A huge change was also indicated by the alteration in the proportion of exchangeable cations. In the $150 \mathrm{~kg} \cdot \mathrm{ha}^{-1} \cdot \mathrm{year}^{-1} \mathrm{~N}$ treatment, the ratio of $\mathrm{Ca}^{2+}$ dropped to $35 \%$, while the rate of toxic $\mathrm{Al}^{3+}$ and $\mathrm{Fe}^{2+}$ increased. With the application of alginit, the ratio of $\mathrm{Ca}^{2+}$ rose to $80 \%$, similarly to that in neutral soils, while the rate of toxic $\mathrm{Al}$ and $\mathrm{Fe}$ ions dropped to a tenth and a quarter, respectively. Therefore, the application of alginit at a dose of $100 \mathrm{t} \cdot \mathrm{ha}^{-1}$ may result in the amelioration and chemical modification of acidic sandy soils (Table 5).

Effect of $N x$ alginit treatments on the $\mathrm{NH}_{4}$-acetate $+E D T A$ soluble element content of the soil in the ploughed layer

The $\mathrm{NH}_{4}$-acetate + EDTA-soluble element content is an important characteristic in agronomic and environmental studies. It refers to the mobility and potential plant uptake of the element, as well as to the absence or abundance of a certain element.

The data in Table 6 , in agreement with those in Tables 4 and 5, reflect the impact of large-scale, long-term $\mathrm{N}$ fertilization on the loss/excretion of $\mathrm{Ca}$ and $\mathrm{Mg}$ in the topsoil, and on the harmful accumulation of Fe and Al. In terms of $\mathrm{N}$ treatment means, the application of alginit (which enriched the topsoil with approx. $5 \mathrm{t} \cdot \mathrm{ha}^{-1}$ elemental Ca) increased the soluble $\mathrm{Ca}$ content nearly 5 -fold. The treated soil was also enriched in soluble $\mathrm{K}, \mathrm{Mg}$ and $\mathrm{P}$. The solubility of undesirable elements decreased slightly.

It can be observed that parallel with the high $\mathrm{N}$ load and acidification, the most important micro-nutrients in the soil (e.g. $\mathrm{Mn}, \mathrm{Na}, \mathrm{Ba}, \mathrm{Sr}, \mathrm{Ni}$ ) also declined, leading to the impoverishment of the topsoil. After alginit treatment, the concentration of these elements increased. The Sr content increased greatly, by nearly 5 -fold.

It is known that $\mathrm{Sr}$ is an accompanying element to $\mathrm{Ca}$. Its content in rocks and soils may be about $1 \%$ of that of $\mathrm{Ca}$. This $\mathrm{Ca}: \mathrm{Sr}$ ratio of about 100 is also typical of alginit. Other element concentrations were about Co $0.25 \mathrm{mg} \cdot \mathrm{kg}^{-1}, \mathrm{Cr} 0.10 \mathrm{mg} \cdot \mathrm{kg}^{-1}$, Mo and $\mathrm{Cd} 0.01 \mathrm{mg} \cdot \mathrm{kg}^{-1}$ regardless of the treatment (Table 6).

Table 6

Effect of alginit treatments on the $\mathrm{NH}_{4}$-acetate+EDTA-soluble element contents in the ploughed layer of the soil, averaged over $\mathrm{N}$ treatments, 2012 (Brown forest soil, acid sand, Nyírlugos)

\begin{tabular}{|c|c|c|c|c|}
\hline \multirow{2}{*}{$\begin{array}{c}\text { N treatment } \\
\text { means }\end{array}$} & $\mathrm{Ca}$ & $\mathrm{K}_{2} \mathrm{O}$ & $\mathrm{Mg}$ & $\mathrm{Ba}$ \\
\cline { 2 - 5 } & \multicolumn{3}{|c|}{$\mathrm{mg} \cdot \mathrm{kg}^{-1}$} & $\mu \mathrm{g} \cdot \mathrm{kg}^{-1}$ \\
\hline Control & 154 & 50 & 18 & 3.6 \\
\hline Alginit & 730 & 62 & 104 & 4.8 \\
\hline LSD $_{5 \%}$ & 116 & 5 & 12 & 0.5 \\
\hline F-value & $* * *$ & $* * *$ & $* * *$ & $* * *$ \\
\hline
\end{tabular}

Note: Fe 120, Al 105, $\mathrm{P}_{2} \mathrm{O}_{5}$ 101, S 8, Na 7, Zn 0.6-0.9 mg $\cdot \mathrm{kg}^{-1}$, Co 250, Cr 100, Mo 20, $\mathrm{Cd} 10 \mu \mathrm{g} \cdot \mathrm{kg}^{-1}$ regardless of the treatment 


\section{Effect of $N x$ alginit treatments on the yield of triticale}

The development of the crop stand in each plot was evaluated on a 1-5-scale three times during the vegetation period: at tillering, flowering and harvest. It was established that alginit application had a significantly positive effect on triticale development, especially in the $150 \mathrm{~kg} \cdot \mathrm{ha}^{-1} \cdot \mathrm{year}^{-1} \mathrm{~N}$ treatment, which had become acidified and infertile during the 50 years of the long-term experiment (Table 7).

Table 7

Effect of $\mathrm{N} \mathrm{x}$ alginit treatments on the height and air-dry weight of triticale at harvest, 2012

\begin{tabular}{|c|c|c|c|c|c|c|}
\hline $\mathrm{N}$ rate & Height & Grain & By-products & Biomass & \multirow{2}{*}{$\begin{array}{c}\text { By- } \\
\text { products/ } \\
\text { grain }\end{array}$} & $\begin{array}{c}\text { Grain } \\
\text { weight }\end{array}$ \\
\hline $\mathrm{kg} \cdot \mathrm{ha}^{-1} \cdot \mathrm{yr}^{-1}$ & $\mathrm{~cm}$ & \multicolumn{3}{|c|}{$\mathrm{t} \cdot \mathrm{ha}^{-1}$} & & $\mathrm{~g} \cdot 100^{-1} \cdot \mathrm{yr}^{-1}$ \\
\hline \multicolumn{7}{|c|}{ Control } \\
\hline 0 & 49 & 1.30 & 1.57 & 2.87 & 1.2 & 35 \\
\hline 50 & 60 & 1.86 & 2.44 & 4.29 & 1.3 & 54 \\
\hline 100 & 62 & 2.15 & 2.54 & 4.70 & 1.2 & 65 \\
\hline 150 & 55 & 1.18 & 1.74 & 2.92 & 1.5 & 31 \\
\hline \multicolumn{7}{|c|}{ Alginit, $100 t \cdot h a^{-1}$} \\
\hline 0 & 56 & 2.01 & 2.36 & 4.37 & 1.2 & 58 \\
\hline 50 & 63 & 3.31 & 3.75 & 7.06 & 1.2 & 81 \\
\hline 100 & 68 & 3.87 & 4.52 & 8.39 & 1.2 & 97 \\
\hline 150 & 64 & 3.38 & 3.93 & 7.31 & 1.2 & 76 \\
\hline $\mathrm{LSD}_{5 \%}$ & 8 & 0.72 & 0.72 & 1.40 & 0.2 & 18 \\
\hline \multicolumn{7}{|c|}{ Means of $N$ treatments } \\
\hline Control & 57 & 1.62 & 2.07 & 3.69 & 1.3 & 46 \\
\hline Alginit & 63 & 3.14 & 3.64 & 6.78 & 1.2 & 78 \\
\hline $\mathrm{LSD}_{5 \%}$ & 4 & 0.36 & 0.36 & 0.70 & 1.0 & 9 \\
\hline F-value & $* *$ & $* * *$ & $* * *$ & $* * *$ & $* *$ & $* * *$ \\
\hline
\end{tabular}

In the first year following the alginit treatment, no rain fell for a month after the triticale was sown $\left(14^{\text {th }}\right.$ October 2011), so emergence was delayed. At this stage, no positive effect of the alginit could be detected

Maximum plant height and yield were achieved with the $100 \mathrm{~kg} \cdot \mathrm{ha}^{-1} \cdot \mathrm{yr}^{-1} \mathrm{~N}$ dose on control plots. The greatest $\mathrm{N}$ effects in both the vegetative and reproductive stages (by-products, grain weight per year and 1000-kernel weight) were obtained with this $\mathrm{N}$ dose. In the $150 \mathrm{~kg} \cdot \mathrm{ha}^{-1} \cdot \mathrm{yr}^{-1}$ treatment, where the soil acidified to the greatest extent over the decades, plant height and yield mass decreased significantly. However, the decline in the weight of the by-products (straw + chaff) was less pronounced than for the grain, so the by-products/crop ratio increased and the harvest index deteriorated. With the application of alginit, the average height of the plants significantly increased, the grain yield almost doubled and the aboveground 
biomass increased from $3.7 \mathrm{t} \cdot \mathrm{ha}^{-1}$ to $6.8 \mathrm{t} \cdot \mathrm{ha}^{-1}$. The harvest index improved, mainly because of the sharp increase in the g/spike and 1000-grain weight parameters.

Earlier experience showed that both extremely wet and extremely dry years lead to drastic yield reductions. In very wet periods the crop thinned, stalk and root rot diseases and fungi occurred and weeds proliferated. In the hot summer months, water shortage occurs very rapidly on sandy soil and the vegetation may be desiccated and dry out.

In 2013, and to some extent in 2012, both the abundance of rainfall in the vegetative phase and the water deficit/drought in the reproductive phase had a devastating effect. During the growing season weather conditions may have different effects on the formation of different yield elements (plant density at emergence, number of spikes at tillering, and thousand-seed weight during maturation).

Favourable weather may increase the 1000 -seed weight in the generative phase, thus slightly offsetting, for example, the negative effects experienced in the vegetative phase, or vice versa. The negative and positive effects may be additive. The yield develops as the result of interactions between different factors.

As Table 8 shows, in 2013 alginit failed to have a spectacularly positive impact, although the effects were significant. The grain yield remained below $1 \mathrm{t} \cdot \mathrm{ha}^{-1}$ and the aboveground biomass of triticale ranged from 1.5 to $3.0 \mathrm{t} \cdot \mathrm{ha}^{-1}$. The air-dry weed mass was approx. $50 \%$ of that of triticale (aboveground parts) at harvesting. It is worth mentioning that no chemical weed control was applied in the experiment.

Table 8

Effect of $\mathrm{N} x$ alginit treatments on the height and air-dry yield of triticale and on the air-dry weed biomass at harvest, 2013

\begin{tabular}{|c|c|c|c|c|c|c|}
\hline $\mathrm{N}$ rate & Height & Grain & By-products & Triticale & \multirow{2}{*}{$\begin{array}{l}\text { By-products/ } \\
\text { grain }\end{array}$} & \multirow{2}{*}{$\frac{\text { Weeds }}{\mathrm{t} \cdot \mathrm{ha}^{-1}}$} \\
\hline $\mathrm{kg} \cdot \mathrm{ha}^{-1} \cdot \mathrm{yr}^{-1}$ & $\mathrm{~cm}$ & \multicolumn{3}{|c|}{$\mathrm{t} \cdot \mathrm{ha}^{-1}$} & & \\
\hline \multicolumn{7}{|c|}{ Control } \\
\hline 0 & 44 & 0.73 & 1.47 & 2.20 & 2.1 & 1.1 \\
\hline 50 & 36 & 0.49 & 1.25 & 1.74 & 2.7 & 1.0 \\
\hline 100 & 39 & 0.54 & 1.34 & 1.88 & 2.6 & 1.0 \\
\hline 150 & 38 & 0.38 & 1.10 & 1.48 & 3.6 & 0.9 \\
\hline \multicolumn{7}{|c|}{ Alginit, $100 t \cdot h a^{-1}$} \\
\hline 0 & 47 & 0.93 & 1.83 & 2.76 & 2.0 & 1.1 \\
\hline 50 & 43 & 0.69 & 1.70 & 2.38 & 2.5 & 1.1 \\
\hline 100 & 50 & 0.76 & 1.68 & 2.43 & 2.5 & 1.7 \\
\hline 150 & 49 & 0.89 & 2.11 & 3.00 & 2.4 & 1.2 \\
\hline $\mathrm{LSD}_{5 \%}$ & 5 & 0.30 & 0.46 & 0.73 & 1.1 & 0.5 \\
\hline \multicolumn{7}{|c|}{ Means of $N$ treatments } \\
\hline Control & 39 & 0.53 & 1.29 & 1.82 & 2.7 & 1.0 \\
\hline Alginit & 47 & 0.81 & 1.83 & 2.64 & 2.4 & 1.3 \\
\hline $\mathrm{LSD}_{5 \%}$ & 3 & 0.15 & 0.23 & 0.37 & 0.6 & 0.3 \\
\hline F-value & $* * *$ & $* * *$ & $* * *$ & $* * *$ & & $*$ \\
\hline
\end{tabular}


The year 2014 was favourable for the development of triticale. Extremely pronounced $\mathrm{N}$ effects prevailed in this wet year.

Alginit treatment dramatically increased the efficiency of $\mathrm{N}$ fertilization. Due to the application of both $\mathrm{N}$ and alginit, the grain and straw yield of triticale increased 5 -fold, reaching $10.5 \mathrm{t} \cdot \mathrm{ha}^{-1}$ air-dry biomass on plots treated with $150 \mathrm{~kg} \cdot(\mathrm{ha} \cdot \mathrm{yr})^{-1} \mathrm{~N}$. The air-dry weed mass was increased slightly by alginit treatment, while on the control plots the higher triticale yield resulted from the abundant $\mathrm{N}$ supply that suppressed the weeds (Table 9).

Table 9

Effect of $\mathrm{N} \mathrm{x}$ alginit treatments on the height and air-dry yield of triticale and on the air-dry weed biomass at harvest, 2014 (Brown forest soil, acid sand, Nyírlugos)

\begin{tabular}{|c|c|c|c|c|c|c|}
\hline $\mathrm{N}$ rate & Height & Grain & $\begin{array}{c}\text { By- } \\
\text { products }\end{array}$ & Triticale & \multirow{2}{*}{$\begin{array}{l}\text { By-products/ } \\
\text { grain }\end{array}$} & Weeds \\
\hline $\mathrm{kg} \cdot \mathrm{ha}^{-1} \cdot \mathrm{yr}^{-1}$ & $\mathrm{~cm}$ & \multicolumn{3}{|c|}{$\mathrm{t} \cdot \mathrm{ha}^{-1}$} & & $\mathrm{t} \cdot \mathrm{ha}^{-1}$ \\
\hline \multicolumn{7}{|c|}{ Control } \\
\hline 0 & 40 & 0.44 & 0.67 & 1.10 & 1.3 & 1.8 \\
\hline 50 & 51 & 0.62 & 1.36 & 1.97 & 2.2 & 1.2 \\
\hline 100 & 54 & 0.62 & 1.85 & 2.47 & 3.2 & 1.0 \\
\hline 150 & 62 & 1.85 & 3.70 & 5.55 & 2.0 & 0.8 \\
\hline \multicolumn{7}{|c|}{ Alginit, $100 t \cdot h a^{-1}$} \\
\hline 0 & 43 & 0.68 & 1.09 & 1.77 & 1.6 & 2.0 \\
\hline 50 & 62 & 1.60 & 3.46 & 5.05 & 2.4 & 1.4 \\
\hline 100 & 61 & 1.51 & 2.67 & 4.18 & 1.9 & 2.2 \\
\hline 150 & 72 & 3.81 & 6.73 & 10.54 & 1.8 & 1.1 \\
\hline $\mathrm{LSD}_{5 \%}$ & 10 & 0.84 & 1.18 & 1.84 & 1.0 & 0.9 \\
\hline \multicolumn{7}{|c|}{ Means of $N$ treatments } \\
\hline Control & 52 & 0.88 & 1.89 & 2.77 & 2.2 & 1.2 \\
\hline Alginit & 59 & 1.90 & 3.49 & 5.39 & 1.9 & 1.7 \\
\hline $\mathrm{LSD}_{5 \%}$ & 5 & 0.42 & 0.60 & 0.94 & 0.5 & 0.5 \\
\hline F-value & $* *$ & $* * *$ & $* * *$ & $* * *$ & & \\
\hline
\end{tabular}

\section{Effect of $N x$ alginit treatments on the element contents of straw and grain}

As shown in Table 10, the analysis of element composition in 2012 showed that on the control soil $\mathrm{K}$ became concentrated in the straw, while $\mathrm{Mg}$ was diluted as the $\mathrm{N}$ rates increased (decrease in $\mathrm{pH}$, acidification). The well-known relationship between plant Mn uptake and $\mathrm{pH}$ was reflected in the Mn accumulation on acidifying soil. Alginit treatment resulted in increasing $\mathrm{Ca}$ and $\mathrm{Mg}$ and decreasing $\mathrm{Mn}$ concentrations in the straw (liming effect). According to the analysis the effect of $100 \mathrm{t} \cdot \mathrm{ha}$ ${ }^{1}$ alginit corresponded to that of $15.4 \mathrm{t} \cdot \mathrm{ha}^{-1} \mathrm{CaCO}_{3}$, which is an ameliorating liming 
dose. The quantity of S applied was $124 \mathrm{~kg} \cdot \mathrm{ha}^{-1}$. The $\mathrm{S}$ concentration of the straw rose from $0.07 \%$ to $0.12 \%$ in response to alginit application.

With the increasing $\mathrm{N}$ supply and acidification, the concentrations of $\mathrm{Zn}, \mathrm{Ba}$ and Co increased, while Mo decreased in the straw. The liming effect of alginit reduced the accumulation of $\mathrm{Zn}$ and $\mathrm{Ba}$, and even of $\mathrm{Cu}, \mathrm{Co}$ and $\mathrm{Ni}$ averaged over the $\mathrm{N}$ treatments.

Table 10

Effect of alginit treatment on the element content of air-dry triticale straw and grain at harvest in 2012, averaged over $\mathrm{N}$ treatments (Brown forest soil, acid sand, Nyírlugos)

\begin{tabular}{|c|c|c|c|c|c|c|}
\hline \multicolumn{7}{|c|}{ STRAW } \\
\hline $\begin{array}{l}\mathrm{N} \text { treatment } \\
\text { means }\end{array}$ & K & $\mathrm{Ca}$ & $\mathrm{Mg}$ & $\mathrm{P}$ & $\mathrm{S}$ & $\mathrm{Mn}$ \\
\hline & \multicolumn{5}{|c|}{$\%$} & $\mathrm{mg} \cdot \mathrm{kg}^{-1}$ \\
\hline Control & 0.80 & 0.18 & 0.06 & 0.10 & 0.07 & 221 \\
\hline Alginit & 0.71 & 0.23 & 0.13 & 0.11 & 0.12 & 126 \\
\hline $\mathrm{LSD}_{5 \%}$ & 0.10 & 0.04 & 0.02 & 0.02 & 0.02 & 44 \\
\hline F-value & & $* *$ & $* * *$ & & $* * *$ & $* * *$ \\
\hline $\begin{array}{c}\mathrm{N} \text {-treatments } \\
\text { means }\end{array}$ & $\mathrm{Zn}$ & $\mathrm{Ba}$ & $\begin{array}{c}\mathrm{Cu} \\
\mathrm{mg} \cdot \mathrm{kg}^{-1}\end{array}$ & $\mathrm{Ni}$ & Mo & $\begin{array}{c}\mathrm{Co} \\
\mu \mathrm{g} \cdot \mathrm{kg}^{-1}\end{array}$ \\
\hline Control & 16.6 & 19.7 & 5.2 & 3.0 & 0.39 & 164 \\
\hline Alginit & 12.6 & 10.7 & 4.6 & 2.1 & 1.42 & 103 \\
\hline $\mathrm{LSD}_{5 \%}$ & 2.2 & 2.3 & 0.5 & 0.7 & 0.50 & 37 \\
\hline F-value & $* *$ & $* * *$ & $*$ & $*$ & $* * *$ & $* *$ \\
\hline \multicolumn{7}{|c|}{ GRAIN } \\
\hline $\begin{array}{c}\mathrm{N} \text { treatment } \\
\text { means }\end{array}$ & $\mathrm{Mg}$ & $\mathrm{Mn}$ & $\mathrm{Zn}$ & $\mathrm{Ba}$ & Mo & $\mathrm{Cd}$ \\
\hline & $\%$ & & $\mathrm{mg} \cdot \mathrm{kg}^{-1}$ & & \multicolumn{2}{|c|}{$\mu \mathrm{g} \cdot \mathrm{kg}^{-1}$} \\
\hline Control & 0.11 & 90 & 36 & 2.4 & 200 & 27 \\
\hline Alginit & 0.14 & 42 & 32 & 0.4 & 889 & 63 \\
\hline $\mathrm{LSD}_{5 \%}$ & 0.02 & 13 & 3 & 0.6 & 184 & 8 \\
\hline F-value & $* * *$ & $* * *$ & $* *$ & $* * *$ & $* * *$ & $* * *$ \\
\hline
\end{tabular}

Notes: In the straw, values of $\mathrm{Al} 127, \mathrm{Fe} 136, \mathrm{Na} 18, \mathrm{Sr} 14, \mathrm{~B} 5 \mathrm{mg} \cdot \mathrm{kg}^{-1}$; $\mathrm{Cr} 225, \mathrm{Cd} 105 \mu \mathrm{g} \cdot \mathrm{kg}^{-1}$ were recorded on average, independently of the treatment. In the grain the following elements were below the given detection limits: Se 600, As 400, Pb 300, Ni 200, $\mathrm{Hg}, \mathrm{Cr} 100, \mathrm{Co} 40 \mu \mathrm{g} \cdot \mathrm{kg}^{-1}$

Mo is known to become mobile in an alkaline medium, so it is more readily available for plants in the form of molybdenum anions. Therefore, the Mo supply of soils in the Nyírség region can be improved by alginit treatment, which could be beneficial from both the agronomic and physiological/nutritional point of view. It is worth noting that the concentrations of the following elements were independent of the treatment: Al 127, Fe 136, Na 18, Sr 14, B $5 \mathrm{mg} \cdot \mathrm{kg}^{-1}$, and $\mathrm{Cr} 225, \mathrm{Cd} 105$ $\mu \mathrm{g} \cdot \mathrm{kg}^{-1}$ on average. The following elements were below the given detection limits: Se 0.12; Hg 0.10; As 0.08; Sn $0.05 \mathrm{mg} \cdot \mathrm{kg}^{-1}$ (Table 10). 
The grains are genetically better protected, so the treatment effects were less pronounced. On the control soil the concentrations of the macroelements $\mathrm{K}, \mathrm{P}, \mathrm{S}$, $\mathrm{Mg}$ and $\mathrm{Ca}$ did not change substantially with changes in the $\mathrm{N}$ supply.

However, Mn accumulation was pronounced, as in the case of the straw. The liming effect of alginit was indicated by the elevated $\mathrm{Mg}$ and $\mathrm{Ca}$ contents and by the decrease in $\mathrm{Mn}$. The $\mathrm{S}$ content of the grain also increased slightly, but not significantly.

On the control soil higher $\mathrm{Zn}, \mathrm{Fe}$ and $\mathrm{Ba}$ contents and lower Mo contents were measured as the $\mathrm{N}$ doses increased (acidification). After alginit treatment $\mathrm{Cd}$ decreased and the incorporation of Mo rose 4-fold, averaged over the $\mathrm{N}$ treatments. The concentrations of the elements $\mathrm{As}, \mathrm{Co}, \mathrm{Cr}, \mathrm{Hg}, \mathrm{Ni}, \mathrm{Pb}$ and $\mathrm{Se}$ remained below the detection limit.

\section{Summary}

The effect of alginit on the soil and on triticale was studied over three years, from 2012 to 2014, in a long-term field experiment set up on acidic sandy soil in Nyírlugos 53 years ago. A $100 \mathrm{t} \cdot \mathrm{ha}^{-1}$ rate of alginit was applied in autumn 2011 on plots given $0,50,100$ and $150 \mathrm{~kg} \cdot \mathrm{ha}^{-1} \cdot \mathrm{year}^{-1} \mathrm{~N}$. The originally $5 \times 10=50 \mathrm{~m}^{2}$ plots were halved, and the halves without alginit treatment served as controls. The $4 \mathrm{~N}+$ $4 \mathrm{~N}$ (with alginit) $=8$ treatments $\times 4$ replications $=32$ plots. The main results are as follows:

1. Physical soil measurements showed that alginit treatment had no effect on the total porosity or water capacity of the soil. The field capacity increased by $4.4 \%$ on average, but this was not significant. The saturation percentage $\left(\mathrm{K}_{\mathrm{A}}\right.$ according to Arany) rose significantly from 30.2 to 31.6 .

2. On alginit-treated plots the $\mathrm{pH}(\mathrm{KCl})$ increased from 3.9 to 6.2 , $\mathrm{CEC}$ from 1.3 to $3.6, \mathrm{EC}$ from 21 to $67 \mathrm{~ms} / \mathrm{cm}$ and base saturation from $53 \%$ to $74 \%$, while the hydrolytic acidity decreased from 10 to 6 after the first year.

3. $\mathrm{NH}_{4}$-acetate + EDTA-soluble $\mathrm{Ca}$ increased from 154 to $730, \mathrm{~K}_{2} \mathrm{O}$ from 50 to 62, $\mathrm{Mg}$ from 18 to $104, \mathrm{Sr}$ from 0.9 to $4.4 \mathrm{mg} \cdot \mathrm{kg}^{-1}$ and Ni from 125 to $330 \mu \mathrm{g} \cdot \mathrm{kg}^{-1}$ on the alginit-treated plots.

4. The straw and grain yield of triticale increased in all three years. Alginit treatment generally doubled the yields, especially on plots treated with $150 \mathrm{~kg} \cdot \mathrm{ha}$ ${ }^{1}$. year ${ }^{-1} \mathrm{~N}$, which became acidified and impoverished in $\mathrm{Ca}, \mathrm{Mg}, \mathrm{K}$ and $\mathrm{P}$.

5. Alginit treatment increased the $\mathrm{Mg}$, Mo and $\mathrm{Cd}$ uptake and reduced that of $\mathrm{Mn}, \mathrm{Zn}$ and $\mathrm{Ba}$ by triticale seeds. The $\mathrm{Ca}, \mathrm{Mg}, \mathrm{S}$ and Mo concentrations increased in the straw, while the incorporation of $\mathrm{Mn}, \mathrm{Zn}, \mathrm{Ba}, \mathrm{Cu}, \mathrm{Ni}$ and $\mathrm{Co}$ was inhibited by alginit.

6. Alginit is a suitable mineral for the amelioration of similar acid sands, which may eliminate the acidity caused by excessive $\mathrm{N}$ supplies and improve the water holding capacity, colloidal and nutrient status and drought-tolerance, and thus their fertility. 
Keywords: alginit, soil amendment, fertilizer, field experiment, acid soil

\section{References}

ALGINIT, 1999. A soil- ameliorating and conditioning mineral found in Hungary (In Hungarian). Alginit Kitermelő és Értékesítő Kft. Budapest.

BANOS, J., 1999. Unlimited wealth. Alginit: a treasure that will last for centuries (In Hungarian). Napi Magyarország. Gazdaság. 1999. Január 4.

Baranyai, F., Fekete, A. \& Kovács, I., 1987. Results of soil nutrient analysis in Hungary (In Hungarian). Mezőgazdasági Kiadó. Budapest.

BASCOMB, C., 1964. Rapid method for the determination of cation exchange capacity of calcareous and noncalcareous soils. J. Soil Sci. Food Agric. 15. 821-823.

BuZÁs, I. (Ed.), 1993. Manual of Soil and Agrochemical Analysis 1 (In Hungarian). INDA 4231. Budapest.

Helal, M. I. D., 2010. Alginit field trial in Egypt in the year 2010. Final Report. Terra Natural Resource GmbH. Germany and Switzerland.

Jou, A. S. R., Ayantaja, S. A. \& Ogunwale, J. A., 1976. An evaluation of cation exchange measurements of soils in the tropics. Comm. in Soil Sci. Plant Anal. 7. 751-761.

KÁdÁR, I, Szemes, I, Loch, J. \& LÁNG, I., 2011. 50 years of the Nyírlugos long-term mineral fertilization trial (In Hungarian). MTA Talajtani és Agrokémiai Kutatóintézet. Akaprint. Budapest.

LAKANEN, E. \& ERVIÖ, R., 1971. A comparison of eight extractants for the determination of plant available microelements in soils. Acta Agr. Fenn. 123. $223-$ 232.

LÁNG, I., 1963. Questions raised in the mineral fertilization of sandy soils (In Hungarian). MTA Agrártud. Oszt. Közlem. 22. 431-434.

MSzHK, 2009. Licence for the marketing and utilization of Gérce alginit (In Hungarian). Mezőgazdasági Szakigazgatási Hivatal Központ. Növény, Talaj és Agrárkörnyezetvédelmi Igazgatóság. Budapest.

REX, M. \& SCHERER, H., 2010. Impact of Alginit enrichments of a sandy soil on the soil and plant properties in a vegetation pot experiment. Report of results. Agric. Res. Station Kamperhof. Duisburg. Institute of Crop Science and Resource Conservation-Plant Nutrition. University of Bonn.

SoLTI, G., 1999. Alginit (In Hungarian). ZELBA Kft. Hungary-Magyarország. Piliscsaba. Budapest. (Manuscript)

TNR GMBH, 2010. Alginit - Data Sheet and Specification. Terra Natural Resources GmbH. Switzerland. (www.alginit.com) 